\title{
Investigation of Fungicidal Properties of the Tree Growth Regulator Paclobutrazol to Control Apple Scab
}

\author{
Ryan A. Blaedow, William R. Chaney, Paul C. Pecknold, and Harvey A. Holt
}

\begin{abstract}
Paclobutrazol (PBZ) as a systemic fungicide for control of apple scab (Venturia inaequalis) was investigated in mature (cv. Hopa and Snow Drift) and young sapling (cv. Indian Magic) crabapples (Malus spp.). Treatments consisted of a control and PBZ applied to mature trees at one or two times the recommended rate in April 2002 using the basal drench method. Saplings received either foliar or soil drench applications of PBZ, or foliar applications of propiconazole. Disease assessments of mature trees showed that apple scab symptoms in treated trees were as severe as in untreated ones in the year of treatment but were reduced slightly the year after treatment in 'Hopa' and the third year after treatment in 'Snow Drift.' Growth reduction occurred in all treated trees, suggesting that the PBZ levels needed for growth reduction were not sufficient to control apple scab in the year of treatment. In contrast, a one-time foliar application of PBZ reduced apple scab incidence to levels found in 'Indian Magic' saplings treated every 2 weeks with propiconazole, a fungicide and application method commonly recommended for apple scab control. Delayed uptake and insufficient transport of PBZ to the foliage of mature trees after root drench treatments may account for the lack of apple scab control in the years after treatment, even though growth suppression occurred.
\end{abstract}

Key Words. Apple scab; growth regulator; paclobutrazol; systemic fungicide; Venturia inaequalis.

Paclobutrazol (PBZ) has been used for more than 20 years by the electric utility industry to reduce shoot regrowth after pruning of trees to prevent interference with electric distribution lines. Recently, the use of PBZ has become popular in the management and maintenance of trees and landscape plants because of its growth-retarding properties, along with additional secondary benefits such as induced tolerance to various environmental stresses.

PBZ inhibits both sterol and gibberellin biosynthesis in plants and fungi by interfering with cytochrome $\mathrm{P}_{450^{-}}$ dependent monooxygenase enzymes that catalyze several reactions in the isoprenoid pathway (Fletcher and Hofstra 1988; Rademacher 2000). Many of the most popular fungicides used today rely on the same mode of action, sterol biosynthesis inhibition, for their high degree of fungicidal activity. PBZ is a molecule possessing two asymmetric carbons (two chiral centers) and therefore may exists as one of four isomers, each with a unique stereochemical configuration that influences the growth-inhibiting and fungicidal properties of the molecule. Formulations of PBZ consist of a mixture of two stereoisomers, each with its own unique biological activity (Lurssen 1988). One isomer causes reduced plant growth, whereas the other has fungicidal properties (Baldwin and Wiggins 1984; Sugavanam 1984; Wiggins and Baldwin 1984; Burden et al. 1987).

Fungal diseases that are chronic and caused by pathogens that survive in woody plants during the dormant season are often more difficult to treat than are annually occurring foliar diseases (Jacobs and Berg 2000). The size of trees introduces further difficulties to the management of woody plant diseases, making local introduction of systemic compounds an attractive option. PBZ, a triazole plant growth regulator that is systemically translocated in the transpiration stream, may have sufficient fungicidal activity to control certain woody plant diseases.

In the few studies that have investigated disease control with growth regulators such as PBZ, a reduced incidence of fungal disease is often associated with the fungicidal properties of the compounds (Ali et al. 1979; Fletcher and Gao 1986). PBZ was shown to have weak fungicidal activity against the basidiomycete Chondrostereum purpeum, which causes silverleaf, a common disease in plum, pear, and apple orchards in parts of the United Kingdom (Copas and Williams 1987). Although PBZ was not sufficiently effective to prevent infection through large pruning wounds on fruit trees, application of the compound did reduce colonization of the pathogen after infection and may have augmented the trees' natural antifungal responses.

Foliar applications of PBZ were shown to have fungicidal activity against the apple scab fungus Venturia inaequalis (Michelini et al. 1989). Smiley (personal communication, Bartlett Tree Research Laboratories, Charlotte, NC) reported that applications of PBZ to Photinia spp. drastically reduced the incidence of Entomosporium leaf spot. The average leaf 
spot count per leaf was 14.4 on control plants and 2.4 on plants soil drenched with PBZ. PBZ and several other triazole growth regulators significantly reduced the severity of powdery mildew on Phlox paniculata and Rudbeckia hirta (Hill and Latimer 2004). Mycelial growth and spore germination of eight woody plant pathogens were inhibited by PBZ in vitro (Jacobs and Berg 2000). Fungi tested included the oak wilt fungus Ceratocystis fagacearum and Sphaeropsis sapinea, which causes shoot and tip blight of red pine. Both $C$. fagacearum and the butternut pathogen Sirococcus clavigignenti-juglandacearum were found to be particularly sensitive to the compound (Jacobs and Berg 2000), whereas vesiculararbuscular mychorrizal fungi were not adversely affected (Michelini et al. 1989).

Morphological or physiological changes in host plants induced by tree growth retardants, rather than fungicidal activity, have also been suggested as the cause of the reduced incidence of fungal disease (Davis and Dimond 1952; Beckman 1957; Pennypacker et al. 1982; B. Fraedrich, Bartlett Tree Research Laboratories, pers. comm.).

The potential for PBZ to act as a systemic fungicide, along with its persistence in plants (ranging from 2 to 5 years), would make it a unique tool in controlling a wide variety of woody plant diseases. The purported benefits of protection from fungal disease and other environmental stresses, along with tree growth regulating activity, make PBZ a potentially valuable tool in the management and maintenance of trees in urban areas (Davis and Curry 1991; Fletcher et al. 1999; Chaney 2001). We recently investigated the efficacy of PBZ for the control of apple scab, a primarily foliar disease causing leaf lesions and premature defoliation on susceptible $\mathrm{Ma}$ lus species.

\section{MATERIALS AND METHODS}

Mature crabapples (Malus spp.) of two different varieties, 'Hopa' and 'Snow Drift,' growing at the Purdue University Horticulture Farm in West Lafayette, Indiana, U.S. were treated with PBZ using the basal drench method, and the natural occurrence of apple scab was monitored. The trees were uniformly spaced approximately $4.5 \mathrm{~m}(14.9 \mathrm{ft})$ apart in an orchard-like plantation. All treatments were made on 1 April 2002. Soil was removed around the base of trees to expose root flares, creating a shallow reservoir into which the PBZ suspension was applied. Treatments consisted of (1) basal drench with $500 \mathrm{~mL}(15 \mathrm{fl} \mathrm{oz})$ of water to serve as the control; (2) a basal drench with PBZ at the recommended rate $\left(0.79 \mathrm{~g}\right.$ a.i. diameter $\left.\mathrm{cm}^{-1}\right)$ in $500 \mathrm{~mL}(15 \mathrm{fl} \mathrm{oz})$ of water $(1$ $\times$ PBZ); or (3) a basal drench with PBZ at twice the recommended rate $\left(1.58 \mathrm{~g}\right.$ a.i. diameter $\left.\mathrm{cm}^{-1}\right)$ in $500 \mathrm{~mL}(15 \mathrm{fl} \mathrm{oz})$ of water $(2 \times \mathrm{PBZ})$. All trees with a stem caliper of 11 to 15 $\mathrm{cm}$ (4.4 to 6 in) were assigned to one of the three treatments in a randomized complete block design consisting of 23 and
10 replications of the 'Hopa' (69 trees) and 'Snow Drift' (30 trees) varieties, respectively.

Annual terminal shoot growth was measured to verify the presence and activity of PBZ in the crown. Average annual terminal shoot growth was calculated for each cultivar by measuring the length of the five longest terminal shoots from five randomly selected trees in each treatment. Shoot growth measurements were taken at the end of the growing season in 2002 (210 days after treatment) and during the disease assessments in 2003 and 2004 (428 and 800 days after treatment, respectively).

The occurrence of apple scab was monitored on the leaves of terminal shoots for 26 months after the application of PBZ, allowing adequate time for uptake and translocation of the triazole growth retardant to the foliage. Observations were made periodically during the year of treatment $(50,57$, and 75 days after treatment). However, by early July near-total defoliation of all trees in the orchard prevented further assessments in 2002. Disease incidence was assessed again in June 2003 (428 days after treatment) and for a final time in June 2004 (800 days after treatment). Wet and cool conditions early in the spring of 2002 through 2004 resulted in high disease incidence for both cultivars each year. Disease incidence (measured as the percentage of infected leaves) was calculated for each treatment by assessing the 10 youngest leaves on each of 12 terminal shoots for each tree. Three shoots in each of the four cardinal directions were selected near eye level for assessment.

On 18 April 2002, 150 'Indian Magic' crabapple saplings (whips) were planted between the mature crabapples in the orchard described above. At the time of planting, all whips

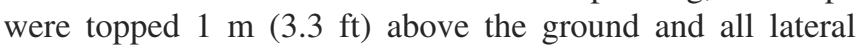
shoots were removed. The whips were randomly assigned to one of six treatment groups in a randomized complete block design to determine the efficacy of PBZ, applied as a basal drench method or by foliar application, for apple scab control. The fungicide propiconazole, commonly used for apple scab control, was also used as a means to judge PBZ's effectiveness in reducing the incidence of apple scab. There were 18 replications for each treatment with the exception of the control, for which 54 replications were used. Treatments for 'Indian Magic' whips included:

1. Control.

2. Basal drench with $\mathrm{PBZ}$ at the recommended rate $(0.79$ g a.i. $\mathrm{cm}^{-1}$ diameter) at the time of planting.

3. Standard spray program: foliar application of propiconazole every 2 weeks 4 days after budbreak.

4. One-time foliar application of PBZ $\left(0.02 \mathrm{~g}\right.$ a.i. $\left.\mathrm{mL}^{-1}\right)$ sprayed until leaf drip, 4 days after budbreak.

5. One-time foliar application of PBZ $\left(0.02 \mathrm{~g}\right.$ a.i. $\left.\mathrm{mL}^{-1}\right)$ sprayed until leaf drip, 4 days after the first heavy infection period, to assess eradicative abilities. 
6. One-time foliar application of propiconazole sprayed until leaf drip, 4 days after the first heavy infection period.

Disease incidence and shoot growth for the 'Indian Magic' whips were assessed in 2002, 53 and 64 days after planting, respectively. The whips were mistakenly killed with an herbicide during routine orchard maintenance early in 2003, and therefore further evaluations could not be conducted. Disease incidence was calculated for each treatment by assessing up to 10 leaves from each of two leaf clusters (the cluster of leaves formed at the base of each new shoot) on each whip. Terminal shoot growth was inadequate to calculate disease incidence on shoot leaves. However, annual growth of the five longest terminal shoots on each whip was measured and averaged for each treatment to verify the presence and activity of PBZ.

Mean disease incidence values for all treatments were transformed using the Arcsin $\left(\operatorname{sine}^{-1}\right)$ transformation. All data were analyzed using ANOVA and the differences between means were determined using the Tukey $w$ procedure $(\alpha=$ $0.05)$. Back-transformed disease incidence values are presented here to ease interpretation of these data.

\section{RESULTS AND DISCUSSION}

Average total annual shoot growth of 'Snow Drift' in 2002 (measured 210 days after treatment) was significantly lower in the $2 \times \mathrm{PBZ}$ trees compared to the controls (Figure 1A).

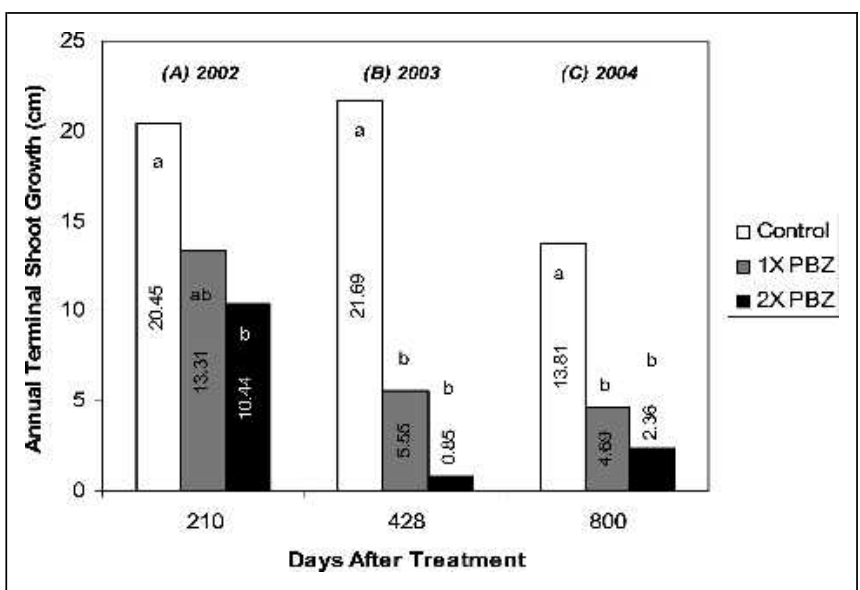

Figure 1. Average annual terminal shoot growth $(\mathrm{cm})$ of 'Snow Drift' crabapple. Treatments consisted of a control (basal drench with $500 \mathrm{~mL}$ ( $15 \mathrm{fl} \mathrm{oz}$ ) of water), $1 \times$ PBZ (a basal drench with PBZ, $0.79 \mathrm{~g}$ a.i. diameter $\mathrm{cm}^{-1}$, in 500 $\mathrm{mL}$ ( $15 \mathrm{fl} \mathrm{oz}$ ) of water), or $2 \times \mathrm{PBZ}$ (a basal drench with PBZ, $1.58 \mathrm{~g}$ a.i. diameter $\mathrm{cm}^{-1}$, in $500 \mathrm{~mL}(15 \mathrm{fl} \mathrm{oz}$ ) of water). Observations were made 210 days ( $A$ ), 428 days (B), and 800 days (C) after treatment application (1 April 2002). Lower-case letters indicate significant differences between means for each evaluation date $(\alpha=0.05)$.
Although the differences in 'Hopa' were not statistically significant, average total annual shoot growth of PBZ treated trees was more than $40 \%$ less than in the controls (Figure 2A). Differences in shoot growth between treated and control trees indicate that PBZ was already present at sufficient levels in the tree canopies to reduce shoot growth in the year of treatment.

In the years subsequent to treatment, terminal shoot growth was significantly reduced in all 'Snow Drift' (Figures 1B and 1C) and 'Hopa' (Figures 2B and 2C) trees treated with PBZ compared to control trees. These results are in agreement with other studies that have concluded that maximum growth regulation may not occur until the year after application (Lever 1986; Wang et al. 1986a,b; Wang and Steffens 1987; Rietveld 1989; Sterrett et al. 1989; Mauk et al. 1990) and confirm the presence of PBZ in the canopies of treated trees throughout the study.

The weather conditions of the 2002 growing season were very conducive to high levels of scab infection. Disease incidence was nearly $100 \%$ on all trees in the orchard by the end of June, followed by almost total defoliation of those trees by early July. PBZ applied in the spring of 2002 did not control apple scab on either 'Snow Drift' or 'Hopa' varieties of crabapple in the summer of that year (Figures 3A and 4A, respectively; data for first two evaluations not shown). The disease incidence in PBZ-treated 'Hopa' was greater than in control trees 75 days after treatment application (Figure 4A); this was due to additional shoot growth and leaf production

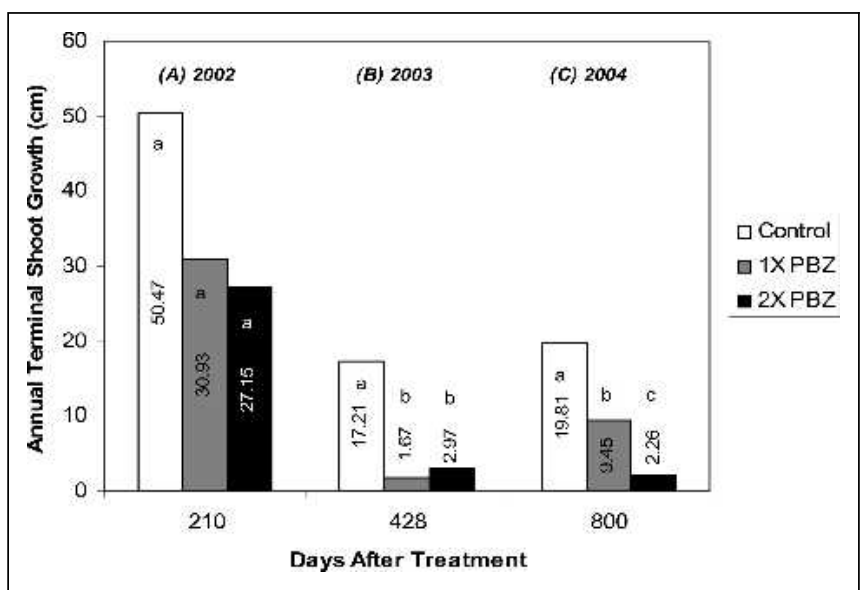

Figure 2. Average annual terminal shoot growth $(\mathrm{cm})$ of 'Hopa' crabapple. Treatments consisted of a control (basal drench with $500 \mathrm{~mL}$ ( $15 \mathrm{fl} \mathrm{oz}$ ) of water), $1 \times$ PBZ (a basal drench with PBZ, $0.79 \mathrm{~g}$ a.i. diameter $\mathrm{cm}^{-1}$, in 500 $\mathrm{mL}$ ( $15 \mathrm{fl} \mathrm{OZ}$ ) of water), or $2 \times$ PBZ (a basal drench with PBZ, $1.58 \mathrm{~g}$ a.i. diameter $\mathrm{cm}^{-1}$, in $500 \mathrm{~mL}(15 \mathrm{fl} \mathrm{Oz}$ ) of water). Observations were made 210 days ( $A$ ), 428 days (B), and 800 days (C) after treatment application (1 April 2002). Lower-case letters indicate significant differences between means for each evaluation date $(\alpha=0.05)$. 


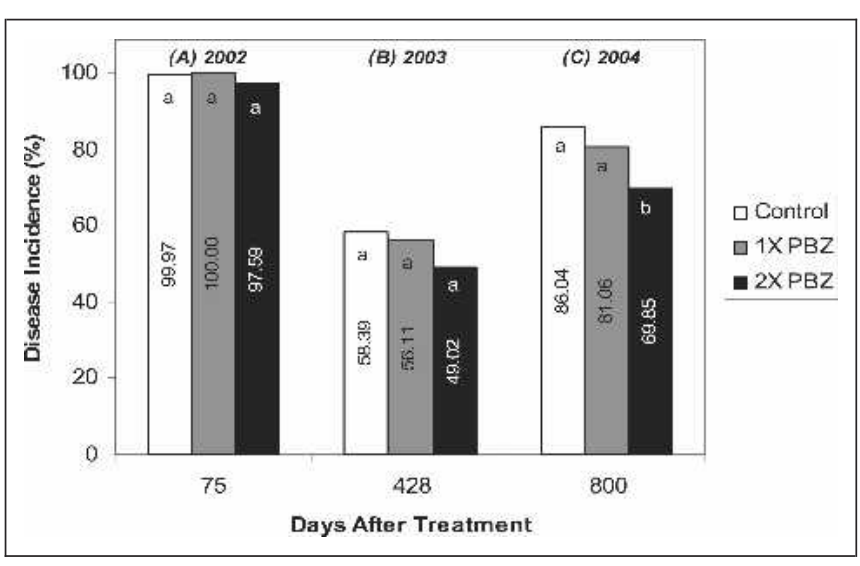

Figure 3. Average incidence of apple scab (\%) on shoot leaves of 'Snow Driff' crabapple. Treatments consisted of a control (basal drench with $500 \mathrm{~mL}$ ( $15 \mathrm{fl} \mathrm{oz}$ ) of water), 1 $\times$ PBZ (a basal drench with PBZ, $0.79 \mathrm{~g}$ a.i. diameter $\mathrm{cm}^{-1}$, in $500 \mathrm{~mL}$ ( $15 \mathrm{fl} \mathrm{Oz}$ ) of water), or $2 \times \mathrm{PBZ}$ (a basal drench with PBZ, $1.58 \mathrm{~g}$ a.i. diameter $\mathrm{cm}^{-1}$, in $500 \mathrm{~mL}$ ( $15 \mathrm{fl} \mathrm{OZ}$ ) of water). Observations were made 75 days (A), 428 days (B), and 800 days (C) after treatment application (1 April 2002). Lower-case letters indicate significant differences between means for each evaluation date $(\alpha=0.05)$.

during the hot and dry summer months when secondary infections did not occur. Trees treated with PBZ produced new leaves at a lower rate, accounting for the higher disease incidence in these treatments.

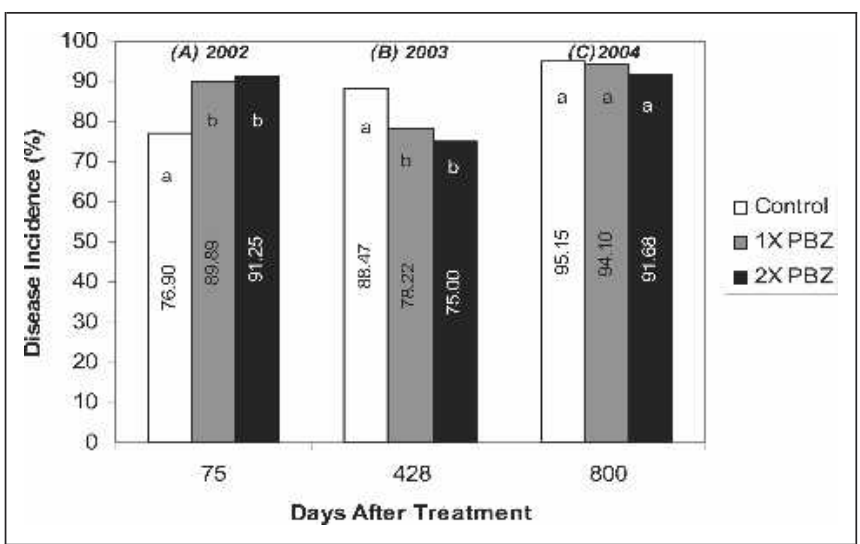

Figure 4. Average incidence of apple scab (\%) on shoot leaves of 'Hopa' crabapple. Treatments consisted of a control (basal drench with $500 \mathrm{~mL}$ ( $15 \mathrm{fl} \mathrm{oz}$ ) of water), 1x PBZ (a basal drench with PBZ, $0.79 \mathrm{~g}$ a.i. diameter $\mathrm{cm}^{-1}$, in $500 \mathrm{~mL}$ ( $15 \mathrm{fl} \mathrm{oz}$ ) of of water), or $2 \times$ PBZ (a basal drench with PBZ, $1.58 \mathrm{~g}$ a.i. diameter $\mathrm{cm}^{-1}$, in $500 \mathrm{~mL}$ ( $15 \mathrm{fl} \mathrm{oz}$ ) of water). Observations were made 75 days (A), 428 days (B), and 800 days (C) after treatment application (1 April 2002). Lower-case letters indicate significant differences between means for each evaluation date $(\alpha=0.05)$.
In 2003, the year after application of PBZ, disease incidence was significantly lower in PBZ-treated 'Hopa' compared to the control trees (Figure 4B). A similar response was not observed for the 'Snow Drift' cultivar (Figure 3B). In 2004 , although the $1 \times$ PBZ rate had no significant effect on disease incidence in 'Snow Drift,' trees treated at twice the recommended rate had a significantly reduced incidence of scab (Figure 3C). No difference was observed between treatments in the 'Hopa' cultivar in 2004 (Figure 4C). Although some significant differences in disease incidence between treatments were seen during the study, the reduction in apple scab incidence was insufficient to prevent near-total defoliation of all trees by the end of July, suggesting that PBZ, when applied as a basal drench, could not be used to control apple scab in these cultivars.

Growth assessment of the 'Indian Magic' whips 64 days after planting showed that of the six treatments, only the foliar applications (treatments 4 and 5) of PBZ reduced shoot growth (Figure 5). The whips that had received treatments 1, 2 , and 6 (control, PBZ basal drench, and one-time treatment with propiconizole after infection, respectively) had a higher disease incidence 53 days after planting than those that had received treatments 3,4 , and 5 (the standard spray program with propiconizole and the foliar applications of PBZ 4 days after budbreak or after heavy infection, respectively) (Figure

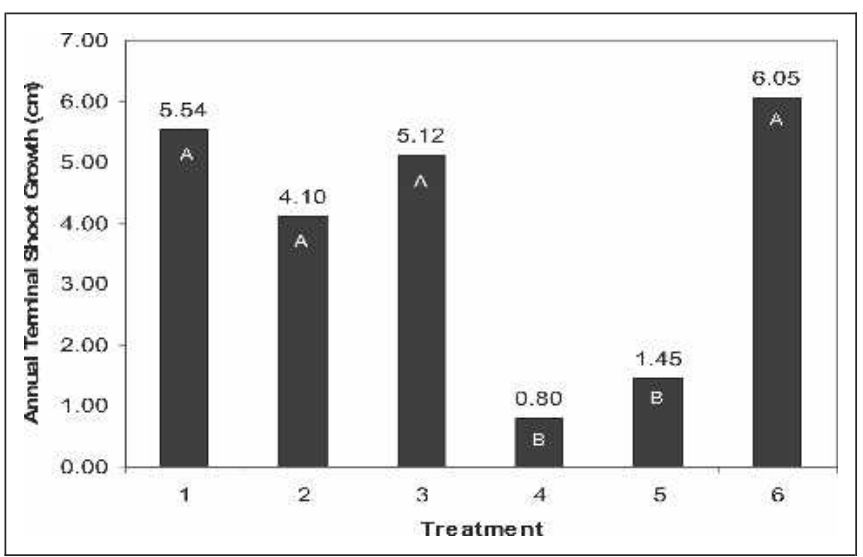

Figure 5. Average annual terminal shoot growth $(\mathrm{cm})$ of 'Indian Magic' crabapple saplings 64 days after planting (22 June 2002). Treatments consisted of (1) control; (2) soil drench with PBZ $\left(0.79 \mathrm{~g}\right.$ a.i. diameter $\left.\mathrm{cm}^{-1}\right)$ at time of planting; (3) foliar application of propiconizole $(0.016 \%$ by volume) every 2 weeks beginning 4 days after budbreak (2 May 2002); (4) foliar application of PBZ (0.02 g $\mathrm{mL}^{-1}$ ) 4 days after budbreak (2 May 2002); (5) foliar application of PBZ $\left(0.02 \mathrm{~g} \mathrm{~mL}^{-1}\right) 4$ days after the first heavy infection period (15 May 2002); and (6) foliar application of propiconizole $(0.016 \%$ by volume) 4 days after the first heavy infection period (15 May 2002). Lower-case letters indicate significant differences between means ( $\alpha=$ 0.05). 
6). There was no significant difference in disease incidence between whips treated with one-time foliar applications of PBZ (treatments 4 and 5) and whips treated every 2 weeks with propiconazole (treatment 3 ) at the time this evaluation was made in mid-June. Significant growth reduction in these PBZ-treated whips shows rapid absorption of the compound by the plants (Figure 5). This strongly suggests that PBZ, in comparison to propiconizole, is either more persistent on the leaf surface (PBZ residue was still visible on the plant surface in October) and is more effective in preventing infection, has greater eradicative ability because of its systemic properties, or both. Another possibility is that PBZ-induced effects on plant growth and development affect the host-parasite interaction, reducing disease incidence in treated plants.

\section{CONCLUSIONS}

No difference was observed in disease incidence that would suggest that PBZ, even at the $2 \times$ rate, was successful in controlling apple scab during the year of treatment in 'Snow Drift' or 'Hopa' crabapple cultivars (Figures 3A and 4A, respectively). In the years after treatment, substantial reductions in shoot growth were accompanied by small and sporadic reductions in disease incidence in PBZ-treated trees. Even when sufficient time was given for compound translocation and subsequent growth reduction in the crown, apple

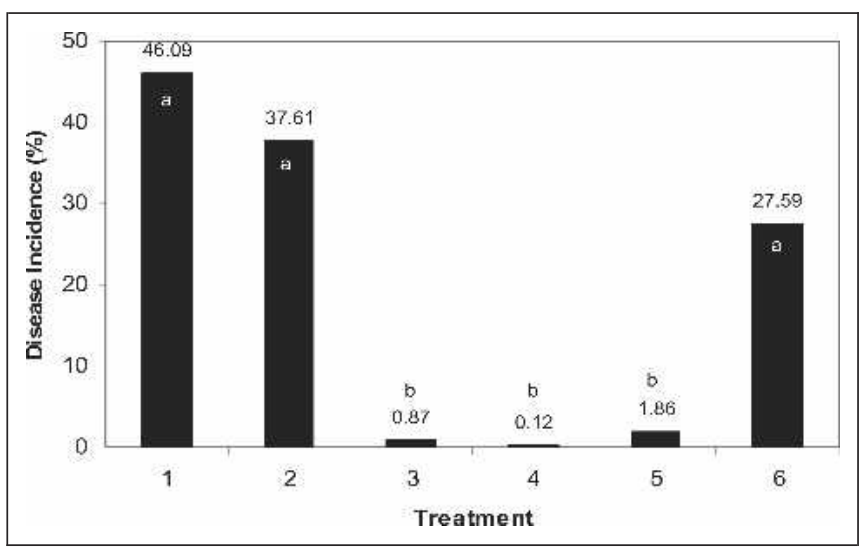

Figure 6. Average incidence of apple scab (\%) on 'Indian Magic' crabapple sapling leaves 53 days after planting (1 1 June 2002). Treatments consisted of (1) control; (2) soil drench with PBZ $\left(0.79 \mathrm{~g}\right.$ a.i. diameter $\left.\mathrm{cm}^{-1}\right)$ at time of planting; (3) foliar application of propiconizole $(0.016 \%$ by volume) every 2 weeks beginning 4 days after budbreak (2 May 2002); (4) foliar application of PBZ (0.02 g $\mathrm{mL}^{-1}$ ) 4 days after budbreak (2 May 2002); (5) foliar application of PBZ $\left(0.02 \mathrm{~g} \mathrm{~mL}^{-1}\right) 4$ days after the first heavy infection period (15 May 2002); and (6) foliar application of propiconizole $(0.016 \%$ by volume) 4 days after the first heavy infection period (15 May 2002). Lower-case letters indicate significant differences between means ( $\alpha=$ 0.05). scab occurrence was not sufficiently reduced in PBZ-treated trees to prevent the unacceptable levels of defoliation that are characteristic of this disease. Near-total defoliation by midsummer occurred in all treatments throughout the study, suggesting that at the rates tested, PBZ applied as a basal drench was not an effective treatment to control apple scab on 'Snow Drift' or 'Hopa' crabapples. The superficial nature of this disease, and the fact that exposure of the fungus to PBZ is unlikely until after infection has occurred, may account for these observations.

A basal drench applied to 'Indian Magic' saplings at the time of planting was equally ineffective in reducing apple scab in the year of treatment. However, a one-time foliar application of PBZ to 'Indian Magic' saplings (treatments 4 and 5) was very successful in controlling apple scab, while the one-time application of propiconazole did not effectively control apple scab (treatment 6). Reduction of disease incidence in saplings by treatment with a foliar application of PBZ was as effective as a standard spray program with propiconazole, resulting in a greater than $90 \%$ reduction in disease incidence compared to the controls (Figure 6). Additional investigations of the mode of action and persistent effectiveness for the control of apple scab of a single foliar application of PBZ early in the growing season are needed. PBZ applied to the foliage for control of apple scab and other woody plant disease could be a unique tool in the management of landscape or orchard trees where growth regulation is acceptable or desired.

Acknowledgment. This research was funded in part by Rainbow Treecare Scientific Advancements, St. Louis Park, MN.

\section{LITERATURE CITED}

Ali, A., R. Hall, and R.A. Fletcher. 1979. Inhibition of fungal growth by plant growth retardants. Canadian Journal of Botany 57:458-460.

Burden, R.S., G.A. Carter, T. Clark, et al. 1987. Comparative activity of the enantiomers of triadimenol and paclobutrazol as inhibitors of fungal growth and plant sterol and gibberellin biosynthesis. Pesticide Science 21:253-267.

Baldwin, B.C., and T.E. Wiggins. 1984. Action of fungicidal triazoles of the diclobutrazol series on Ustilago maydis. Pesticide Science 15:156-166.

Beckman, C.H. 1957. Growth inhibition as a mechanism in Dutch elm disease therapy. Phytopathology 48:172-176.

Chaney, W.R. 2001. Effective plant growth regulators for right-of-ways and potential landscape use. In Proceedings of the 13th Annual Conference of the Western Plant Growth Regulator Society, Monterey, CA, Jan. 10-11, 2001, pp. 39-48.

Copas, L., and R.R. Williams. 1987. Effect of paclobutrazol on the inoculum potential of Chondrostereum purpureum and silverleaf symptoms in cider apple cvs Michelin and 
Sweet Coppin. Journal of Horticultural Science 62: 287-290.

Davis, T.D., and E.A. Curry. 1991. Chemical regulation of vegetative growth. Critical Reviews in Plant Sciences 10: 151-188.

Davis, T.D., and A.E. Dimond. 1952. Inducing disease resistance with plant growth regulator. Phytopathology 43: 137-140.

Fletcher, R.A., and G. Hofstra. 1988. Triazoles as potential plant protectants. In: Berg, D. and M. Plimpel (Eds.). Sterol Biosynthesis Inhibitors: Pharmaceutical and Agrochemical Aspects. Ellis Harwood, Cambridge, MA. pp. 321-331.

Fletcher, R.A., and J.G. Gao. 1986. Comparative fungitoxic and plant growth regulating properties of triazole derivatives. Plant \& Cell Physiology 27:367-371.

Fletcher, R.A., A. Gilley, N. Sankhla, and T.D. Davis. 1999. Triazoles as plant growth regulators and stress protectants. Horticultural Reviews 24:55-138.

Hill, S., and J.G. Latimer. 2004. Effects of plant growth regulators on the severity of powdery mildew on Phlox paniculata 'Blue Boy' and Rudbeckia hirta 'Indian Summer.' In: Ferguson, L. (Ed.). Proceedings of the 31st Annual Meeting of the Plant Growth Regulation Society of America, Charleston, SC, Aug. 1-4, 2004, p. 15.

Jacobs, K.A., and L.C. Berg. 2000. Inhibition of fungal pathogens of woody plants by the plant growth regulator paclobutrazol. Pest Management Science 56:407-412.

Lever, B.G. 1986. 'Cultar'-A technical overview. Acta Horticulturae 179:459-466.

Lurssen, K. 1988. Triazole plant growth regulators: Effects and mode of action. In: Berg, D. and M. Plimpel (Eds.). Sterol Biosynthesis Inhibitors: Pharmaceutical and Agrochemical Aspects. Ellis Harwood, Cambridge, MA. pp. 305-320.

Mauk, C.S., C.R. Unrath, S.M. Blankenship, and L.J. Lehman. 1990. Influence of method of application of paclobutrazol on soil residues and growth retardation in a 'Starkrimson-Delicious' apple orchard. Journal of Plant Growth Regulation 9:27-35.

Michelini, S., L.E. Chinnery, and J.P. Thomas. 1989. The effect of paclobutrazol on the vesicular-arbuscular mycorrhizae of Alemow, Citrus macrophylla Wester, rootstocks. Acta Horticulturae 239:427-430.

Pennypacker, B.W., P.L. Sanders, L. Vann Gregory, et al. 1982. Influence of triadimefon on the foliar growth and flowering of annual bluegrass. Canadian Journal of Plant Pathology 4:259-262.

Rademacher, W. 2000. Growth retardants: Effects on gibberellin biosynthesis and other metabolic pathways. Annual Review of Plant Physiology and Plant Molecular Biology 51:501-531.
Rietveld, W. 1989. Effect of paclobutrazol on conifer seedling morphology and field performance. General Technical Report-Rocky Mountain Forest and Range Experiment Station, USDA Forest Service No. RM-167, pp. 19-23.

Sterrett, J.P., T.J. Tworkoski, and P.T. Kujawski. 1989. Physiological responses of deciduous trees root collar drenched with flurprimidol. Journal of Arboriculture 15: $120-124$.

Sugavanam, B. 1984. Diastereoisomers and enantiomers of paclobutrazol: Their preparation and biological activity. Pesticide Science 15:296-302.

Wang, S.Y., and G.L. Steffens. 1987. Effect of paclobutrazol on accumulation of organic acids and total phenols in apple wood. Journal of Plant Growth Regulation 6: 209-213.

Wang, S.Y., G.L. Steffens, and M. Faust. 1986a. Effect of paclobutrazol on accumulation of carbohydrates in apple wood. HortScience 21:1419-1421.

Wang, S.Y., T. Sun, and M. Faust. 1986b. Translocation of paclobutrazol on cell wall polysaccharide composition of the apple tree. Phytochemistry 25:2493-2496.

Wiggins, T.E., and B.C. Baldwin. 1984. Binding of azole fungicides related to diclobutrazol to cytochrome P-450. Pesticide Science 15:206-209.

Ryan A. Blaedow (corresponding author)

Department of Forestry and Natural Resources

Purdue University

West Lafayette, IN 47907, U.S.

blae0015@umn.edu

William R. Chaney

Department of Forestry and Natural Resources

Purdue University

West Lafayette, IN 47907, U.S.

Paul C. Pecknold

Department of Plant Pathology

Purdue University

West Lafayette, IN 47907, U.S.

Harvey A. Holt

Department of Forestry and Natural Resources

Purdue University

West Lafayette, IN 47907, U.S.

Résume. Le paclobutrazol comme fongicide systémique pour le contrôle de la tavelure (Venturia inaequalis) a été testé avec de jeunes pommetiers - Malus spp. - (cultivar Indian Magic) et des pommetiers matures (Hopa et Snow Drift). Pour les arbres matures, 
ces derniers faisaient soient l'objet d'une application simple ou double de paclobutrazol par arrosage à la base selon le taux recommandé, et ce en avril 2002, soient ils n'étaient l'objet d'aucun traitement pour ceux du groupe témoin. Quant au jeunes arbres, ils ont reçu soient des applications foliaires ou soient des applications par arrosage à la base de paclobutrazol, ou encore des applications foliaires de propiconazole. Les évaluations de maladie sur les arbres matures ont permis d'observer que les symptômes de tavelure sur les arbres traités étaient aussi sévères que ceux sur les arbres non traités, et ce lors de l'année du traitement, mais qu'ils étaient légèrement moindres l'année après le traitement sur Hopa et la troisième année après le traitement sur Snow Drift. Des réductions de croissance se produites chez tous les arbres traités, ce qui laisse à penser que les niveaux de paclobutrazol requis pour une réduction de croissance n'étaient pas suffisants pour contrôler la tavelure lors de l'année d'application. Par comparaison, une seule application foliaire de paclobutrazol a permis de diminuer l'incidence de la maladie à des niveaux observés chez les jeunes arbres du cultivar Indian Magic qui ont été traités aux deux semaines avec le propiconazole, un fongicide avec cette méthode d'application couramment recommandé pour le contrôle de la tavelure. Le délai au niveau de l'assimilation et l'insuffisance du transport du paclobutrazol jusque vers les feuilles des arbres matures après les applications du produit par arrosage sur les racines pourraient expliquer le manque de contrôle de la tavelure qui a été obtenu dans les années qui ont suivi le traitement, et ce même si une réduction de croissance s'est pourtant produite.

Zusammenfassung. Wir untersuchten die Wirkung von $\mathrm{Pa}$ clobutrazol als systemisches Fungizid bei der Kontrolle von Apfelschorf bei reifen und jungen Apfelbäumen. Die Behandlung bestand aus einer Kontrolle und einer Paclobutrazolgabe ein oder zweimal jeweils in der empfohlenen Rate und wurden im April 2002 durch basale Applikation an den reifen Bäumen ausprobiert. Die jungen Schösslinge erhielten entweder Blatt- oder Bodenapplikationen mit Paclobutrazol oder Blattapplikationen mit Propiconazol. Die Untersuchung der Krankheit an den reifen Bäumen zeigte, dass im Jahr der Behandlung der Befall mit Schorf bei den reifen Bäumen so ernst war wie bei den unbehandelten Bäumen, aber in den nachfolgenden Jahren wurde es für einige Kultivare schwächer. Eine Wachstumsreduktion tauchte in allen behandelten Bäumen auf und zeigte, dass Paclobutrazol-Level als Wachstumsregulierer nicht geeignet war, Apfelschorf im Jahr der Behandlung zu reduzieren. Im Gegenteil, eine einmalige Blattapplikation von Paclobutrazol reduzierte den Schorfbefall auf einen Grad, wie er bei jungen 'Indian Magic'Kultivaren, die 14tägig mit Propiconazol in der empfohlenen Rate und Dosis für Apfelschorfbekämpfung empfohlen wurde. Eine verzögerte Aufnahme und ein ungenügender Transport von Paclobutrazol von der Wurzel zum Blattwerk könnte verantwortlich sein für die mangelhafte Apfelschorfkontrolle in den Jahren nach der Behandlung, auch wenn Wachstumsbeschränkungen auftauchten.

Resumen. Se investigó el paclobutrazol, como un fungicida sistémico para el control de la roña del manzano (Venturia inaequalis), en variedades de (Malus spp.): (cv. Hopa y Snow Drift) y (cv. Indian Magic). Los tratamientos, en Abril de 2002, consistieron de un control y el paclobutrazol aplicados a árboles maduros en una o dos veces la tasa recomendada, usando el método de zanja basal. Las muestras recibieron aplicaciones foliares o al suelo de paclobutrazol, o aplicaciones foliares de propiconazole. Las mediciones mostraron que los síntomas de la roña en los árboles tratados fueron igualmente severos como en los no tratados en el año de tratamiento, pero se redujeron levemente al año después del tratamiento, en 'Hopa' y en el tercer año después del tratamiento, en 'Snow Drift'. Hubo reducción del crecimiento en todos los árboles tratados, sugiriendo que los niveles de palobutrazol necesitados no fueron suficientes para el control de la roña en el año del tratamiento. En contraste, una aplicación foliar de paclobutrazol redujo la incidencia de la roña a niveles encontrados en muestras de 'Indian Magic', tratados cada dos semanas con propiconazole, un fungicida y con el método de aplicación comúnmente recomendado para el control de la roña. El retardo de la absorción y el trasporte insuficiente de paclobutrazol al follaje de árboles maduros, después de los tratamientos de zanjas, puede responder por la falta de control de la roña en los años siguientes al tratamiento, aunque sí ocurrió la supresión del crecimiento. 